\title{
State of the art of services in Europe: where are the problems?
}

\author{
Ségolène Aymé \\ From 5th European Conference on Rare Diseases (ECRD 2010) \\ Krakow, Poland. 13-15 May 2010
}

With regard to centres of expertise, the Orphanet database lists 378 centres of expertise, mainly concentrated in Belgium, France, Germany, Italy, Spain and the UK. They cover very different realities as the qualifying criteria to define a centre as an expert centre differ from one country to another, both in terms of the mission and in terms of resources. Some experimental European reference networks of centres of expertise have been established and funded for a three year period only, a time period too short to allow any assessment of the added-value of these networks. With regard to genetic tests, only testing for Cystic fibrosis is provided by every country and over 500 diseases are testable in only one country in Europe. The test offer differs greatly from one large country to another: Germany (1,141 genes), France (874 genes), Italy (625 genes), Spain (582 genes), United Kingdom (414 genes). This situation explains the large cross-border flow of specimens, highlighting the need to provide access to services in other countries when necessary, especially for very rare diseases. With regard to the provision of information to patients and professionals, the difficulty is to maintain updated information about several thousands of diseases and to provide this information in languages understandable by the end users. With regard to funding for research on rare diseases, the multinational common calls for proposals E-Rare now covers Austria, France, Germany, Greece, Israel, Italy, Spain, Turkey, The Netherlands and Portugal. Regarding patient registries, the main problem they face is their sustainability as they are long term projects and most funding sources only support short term projects. The way forward is to establish a public/ private partnership in this area with the support of

Correspondence: segolene.ayme@inserm.fr

Orphanet-Inserm, Plateforme Maladies Rares, 102 rue Didot, 75014 Paris, France regulatory agencies. Among MS, major disparities in access to treatment are also observed.

Published: 19 October 2010

doi:10.1186/1750-1172-5-S1-O2

Cite this article as: Aymé: State of the art of services in Europe: where are the problems? Orphanet Journal of Rare Diseases 2010 5(Suppl 1):O2. Submit your next manuscript to BioMed Central and take full advantage of:

- Convenient online submission

- Thorough peer review

- No space constraints or color figure charges

- Immediate publication on acceptance

- Inclusion in PubMed, CAS, Scopus and Google Scholar

- Research which is freely available for redistribution 